\title{
COMPARATIVE ANALYSIS OF ORGANIZATIONAL AND MANAGERIAL MODELS OF FUNCTIONING OF CUSTOMS ADMINISTRATIONS (ON THE EXAMPLE OF THE CUSTOMS ADMINISTRATION OF SINGAPORE)
}

\begin{abstract}
The purpose of the article is theoretical and methodological substantiation of the mechanisms of state management of customs affairs on the basis of a comparative analysis and the development of directions for their improvement on the example of the customs administration of Singapore.

Research methods. To achieve the purpose of the research, a complex of general scientific and special methods was used. In particular, the following methods were applied:

dialectical - to understand the interconnection between the basic concepts that form the basis of state management of customs;

systemic - to characterize the system of state administration of customs and determine the ownership of the parameters of the customs system;

comparative analysis - to study foreign experience in public administration of customs;

structural and functional - to compare the foreign experience of public administration of customs and determine indicators for diagnostics of the structural and functional dynamics of public administration of customs;

modeling method-for the development of a diagnostic model.

Results. The scientific novelty lies in the theoretical and methodological substantiation of the mechanisms of state management of customs affairs on the basis of a comparative analysis of world experience and determination of the directions for their improvement.

In particular, in the article: the theoretical and methodological substantiation of themechanisms of statemanagement of customs affairs is comprehensively considered and carried out, which will contribute to the implementation of the European principles of strategic development of customs in the modern model of public administration in Ukraine; on the basis of a comparative analysis of the experience of state management of customs affairs, mechanisms and tools for regulating customs relations at the global, regional and national levels are identified and classified. Conclusions. It is important to take into account the experience of the formation and functioning of the Singapore customs service at the stage of searching for an effective model of customs management in Ukraine in the direction of improving the organizational structure, introducing new approaches to the implementation of customs formalities, and strengthening the personnel potential of customs authorities.
\end{abstract}

Key words: simplification of customs procedures, customs administrations, customs formalities, TradeNet, importers, exporters, anti-corruption, smuggling.

JEL Classification: K23, K33, K34, O23, O53, P48.

\section{Viktor CHENTSOV,}

First Vice-Rector

University of Customs and Finance, Doctor of Historical Science, Doctor of Science of Public Administration, Professor

chentsov61@gmail.com

orcid.org/0000-0002-1109-8168

\author{
Natalia TKACHUK, \\ Student \\ Educational and Scientific Institute of \\ Law and International Legal Relations \\ of the University of Customs and \\ Finance, \\ Candidate of Economical Science \\ vnv.vlasenko@gmail.com \\ orcid.org/0000-0001-7848-1076
}

\section{Introduction}

In modern conditions of globalization of the economy, national tax and customs systems are becoming active participants in international relations, becoming one of the important factors in the redistribution of production processes in the context of the global economic system. The deepening of integration processes and the intensification of the activities of international organizations have led to a tendency to equalize the economic conditions in different countries and international regions in many ways. That is why research on the mechanisms of state management of customs affairs as a factor influencing the competitiveness of the national economy is growing, in particular due to the insignificant institutional determinism at the supranational level and the preservation of the sovereign rights of the state to regulate this area. It is also necessary to take into account the role of customs sphere as a factor in the 


\section{Ermek USEKEEV,}

Professor at the Department of

Business and Communication

Kyrgyz National University named

after Jusup Balasagyn,

Doctor of Philosophical Science,

Assistant Professor

ermekadil@gmail.com

orcid.org/0000-0001-7848-1076 development of the national economy. Customs administration in individual countries is now becoming one of the most important elements in ensuring the competitiveness of the national economy. The defining integrated parameter characterizing the efficiency of public administration of customs is the ability of the relevant authorities not only to ensure the financial viability of the state, to guarantee the high quality of public services and social obligations it provides, to promote qualitative and quantitative economic growth, but also to create competitive advantages for the country in struggle to attract additional resources to their own economic environment.

\section{Literature review}

A great contribution to the development of theoretical and methodological problems of the implementation of customs in Ukraine was made by: Ivan Berezhnyuk, Oleksandr Hrebelnyk, Yevhen Dodin, Liliya Dorofyeyeva, Serhiy Dorotych, Yuriy Domin, Serhiy Kivalov, Borys Kormych, Volodymyr Komzyuk, Yuriy Kunyev, Nataliya Lypovska, Anatoliy Mazur, Vasyl Nastyuk, Volodymyr Naumenko, Pavlo Pashko, Dmytro Pryymachenko, Lyudmyla Pysmachenko, Ihor Pysmennyy, Kostyantyn Sandrovskyy, Oleksandr Yehorov and other Ukrainian scientists.

Fundamental research into the problems associated with mechanisms for regulating customs activities at the international, regional and national levels belongs to such scientists and statesmen as: Jean Acri, Olga Bakaeva, Demyan Bakhrakh, Sergey Baramzin, Nikolai Blinov, Paul Brenton, Patricio Castro, Tom Doyle, Paul Durand, Michael Engelschalk, Anthony Estevadeordal, James Ferguson, Theo Ficher, John Fonseca, Boris Gabrichidze, Lothar Gellert, Pravin Gordhan, Andrew Grainger, Stephen Holloway, JanErland Jansson, Michael Keen, Erich Kick, Alexander Kozyrin, Vadim Kukharenko, Michael Lahne, Michael Lux, Takashi Matsumoto, Gerard Mclinden, Kunio Mikuriya, Alexander Nozdrachev, Jose B. Sokol, David Widdowson, Luc de Wolf, Hans Michael Wolfgang and others.

\section{The main text}

Singapore is an important donor country for foreign direct investment. In 2019, Singapore investments abroad totaled 33.0 billion USD.

Singapore is a party to 15 regional trade agreements, including concluded bilateral free trade agreements with the European Free Trade Association (EFTA), USA, Australia, Jordan, India, Japan, Republic of Korea, New Zealand, Panama. (Merezhko et al., 2018).

A feature of Singapore is its location at the crossroads of world trade routes, which is of significant interest to Ukraine. Through Singapore, the access of Ukrainian goods to the market of the countries of South-East Asia with the number of consumers in 3 billion people is realized (Indonesia, Thailand, Malaysia, Philippines, Vietnam, etc.). Trade restrictive measures (anti-dumping and special measures and investigations) are not currently used in bilateral trade between Ukraine and the Republic of Singapore.

After Ukraine gained membership in the WTO, the most favored nation regime is in effect in bilateral trade between Ukraine and the Republic of Singapore. For the Ukrainian side, this means that Singapore has canceled all customs tariffs for Ukrainian goods, except for six items (beer, alcohol, etc.). Having 
opened its market for Ukraine, the Singapore side insists on concluding a bilateral free trade agreement (https://ua.interfax.com.ua/news/economic, 2017).

On August 16, 2019, the Minister of Finance of Ukraine signed the Protocol on Amendments to the Agreement between the Government of Ukraine and the Government of the Republic of Singapore on the avoidance of double taxation in relation to goods exported or imported from states. The Ministry of Finance of Ukraine says that the provisions of the Protocol fully comply with the requirements of the Model Convention of the Organization for Economic Cooperation and Development (Merezhko et al., 2018).

The document provides for a new expanded version of the article "Exchange of information" - without reservations regarding the requirements of national tax interest or bank secrecy, which will lead to improved cooperation between the customs and tax authorities of Ukraine and the Republic of Singapore (Merezhko et al., 2018).

The Agreement guarantees the entrepreneurs of both countries profits received from entrepreneurial activities in the territory of another country, as well as from sources in this country in the form of dividends, interest, royalties. These types of contributions will not be subject to double taxation.

During the visits of state delegations of both countries, agreements were made to hold UkrainianSingaporean business forums, and the introduction of IT in the field of public services in Ukraine (Olujko, 2018). Memorandums of cooperation were signed between the Council of Exporters and Investors under the Ministry of Foreign Affairs and the Singapore-Chinese Chamber of Commerce and Industry, as well as between the Minor Academy of Sciences of Ukraine and the Science Center of Singapore (Olujko, 2018).

The implementation of the agreements largely depends on the coordination of the activities of the customs administrations of both countries.

In connection with the above, an urgent issue is to study the experience of organising the activities of the Singapore customs service.

Singapore Customs Service (hereinafter - S.C.S.) is a separate department under the Ministry of Finance of Singapore. S. C. S. was founded in 1910 under the name of the Central State Customs Department. The main task of the created body was to collect import duties on alcoholic beverages. Over the past 90 years, there have been significant changes in the functions of the customs service, caused by globalization and changes in laws, tariffs and trade. S.C.C. reorganized in 2003 by merging such government bodies as the Department of Duties and Excise (hereinafter - DDE), the Department of Trade and Facilitation (hereinafter - DTF), the Department of Statistics and Audit. At the same time, the functions of border control at checkpoints were transferred to the Department of Immigration and Border Control (hereinafter - DIBC) under the Ministry of Internal Affairs of Singapore (https://news.ati.su/article, 2017).

Singapore Customs Serivice plays an important role in collecting customs duties and simplifying customs procedures. S.C.S. is responsible for the implementation of customs and trade agreements, including free trade agreements concluded with other countries. The customs authorities are tasked with collecting customs revenues, preventing the evasion of customs duties and taxes and complying with the law, and simplifying trade procedures. In addition, the customs authorities themselves are responsible for issuing licenses, certificates of origin and classification decisions.

Main Functions of S.C.S. are:

1. Simplification of customs procedures. S.C.S. provides advisory services and partnerships with businesses across a wide range of industries to identify customer needs through tailored solutions for the business community.

2. Trade regulation. The Singapore Customs Service ensures competitiveness and a level playing field for all businesses, and implements a system of measures aimed at minimising the evasion of customs duties and taxes by importing contraband goods and forging customs declarations.

3. Ensuring the security of trade. S.C.S is a leading trade security agency that is implementing a voluntary certification program for companies seeking to implement robust security measures in their trade operations. This helps to improve the security of the global supply chain.

The Singapore Customs Service is headed by a Director General. The structure of the central office of the administration includes the following subdivisions:

- trade department, 
- Human Resource Management Department,

- planning Department,

- corporate services department,

- information technology department,

- department of statistics and audit,

- Intelligence and Investigation Department.

ORGANIZATIONAL STRUCTURE OF SINGAPORE CUSTOMS

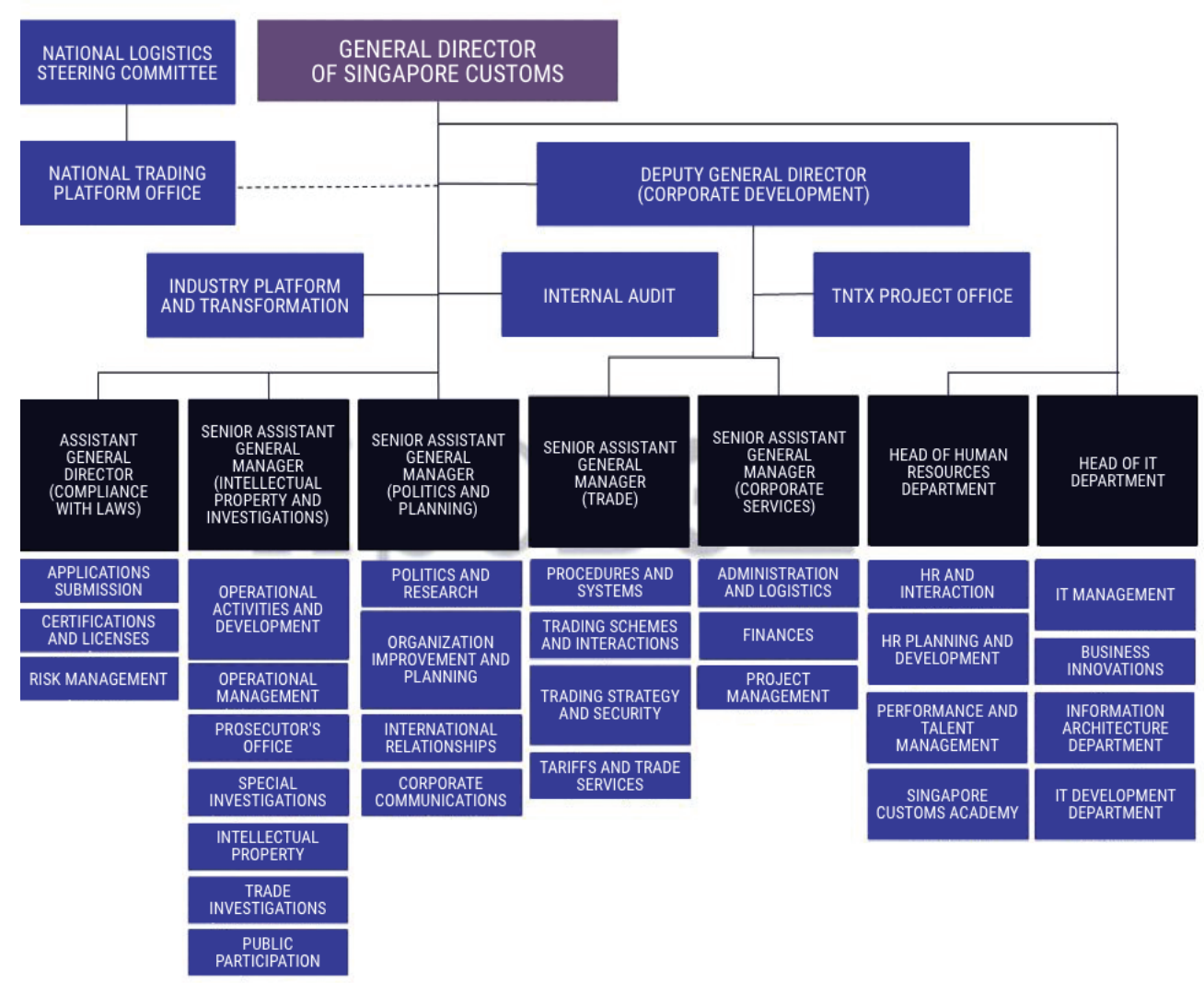

Figure 1. Organizational Structure of Singapore Customs (Koh, 2017)

In addition to the units that are directly related to trade, tariffs and customs investigations, among the key bodies of the department there is a control unit that deals with risk management and control of customs schemes and transactions at enterprises; internal audit units, which are involved in the control of all customs work.

The taxation service of the customs district, as a territorial subdivision, is responsible for the organization, planning and development of activities related to the forms of customs declaration and collection of customs payments, and also deals with the development of tax control and its coordination, management of the implementation by local subdivisions of the collection of excise duty and tax from transport owners. funds. At the local level, in the districts, regional (local) divisions of the customs service function, they directly carry out customs control, registration and collection of customs payments.

The administrative and management structure has been redesigned based on the functions and principles that are dictated by the WTO Framework of Standards (Koh, 2017).

Internal reports in the organization are transmitted directly to the CEO, which greatly simplifies the management decision-making process. In general, the organizational structure was, first of all, adapted to work with business, and it minimized time costs and bureaucratic barriers. (Merezhko et al., 2018). Based on the recommendations of the WTO framework standards, the customs service is now positioning itself, first of all, not as a public authority, but rather as a business structure providing public services. 
The transition to such an organizational structure was the result of the introduction of information technology and changes in the principles of work. The tax administration was reorganized according to functions, not according to the types of taxes collected, the audit unit was strengthened and the work with clients was restructured. In addition, work was separately carried out to streamline the internal procedures for the interaction of the employees themselves.

According to the results of 2016 which was provided by the World Bank, Singapore customs became the fastest and most efficient in the world. These results are presented in the annual study "The Logistics Performance Index and Its Indicators 2016". In total, 160 countries participated in the study, and even the traditional leaders of the rating - Germany and the Netherlands - were ahead of the indicators characterizing the work of the customs authorities of Singapore (Koh, 2017).

According to the research, the country received one of the highest ratings in terms of the convenience of the location of seaports and airports, the speed of customs clearance (less than 1 day for export and 1 day for import) and the share of physical inspections of goods (only 1\%) (Merezhko et al., 2018).

However, the country needs a high level of customs service. The city-state is considered one of the largest ports and economic centers, and firmly holds the first place in the world in terms of the number of ship calls. In addition, free economic zones and technology parks operate in Singapore, which produce products for the foreign and domestic markets, and the city-state's foreign trade turnover is 624.40 million USD, which is one third more than the Russian trade volume. Therefore, lowering customs barriers and simplifying formalities is one of the main factors in attracting investors to the country.

According to the existing system of simplification of customs procedures, TradeNet allows to prepare, submit, receive and process trade declarations and issue the result of consideration. The system covers import declarations (duty / goods and services tax (GST) / non-duty / warehousing / free trade zone), exports (goods and services tax (GST) / non-duty) and transit movement of goods. All customs formalities are carried out using the TradeNet Single Window system (Oluyko, 2016).

The TradeNet system works over the Internet, users can connect to it from anywhere using a web application. The system works around the clock, seven days a week, so the submission and processing of applications is ongoing. With 8,000 users using TradeNet, Internet access saves time and resources. Productivity is improved as a result of a decrease in the total processing time for a trade declaration.

TradeNet allows for quick regulatory and policy changes. For example, you can impose restrictions on the import of certain types of goods from certain countries in connection with any epidemic. At the same time, there is no need to waste time and resources on distributing this information among employees, which is inevitable when submitting documents manually. TradeNet allows timely and accurate application of norms, as well as collection of statistical data for analyzing patterns and identifying possible trends in the import-export of goods.

The main services for importers, exporters and forwarders include the following:

- user and company registration;

- Receiving and forwarding applications for trade permits and certificates of origin from the user (via the Trade Net client software) to the Customs and other regulatory authorities in Singapore for their processing;

- $\quad$ syntactic check of the message structure;

- verification of received applications for compliance with table codes (for example, commodity codes, Harmonized System codes, etc.);

- automatic processing of documentation for the issuance of permits based on the rules and criteria of the customs service and other regulatory authorities of Singapore and others.

TradeNet, the world's first nationwide trade filing system, is recognized as a major contributor to an enabling environment for doing business in Singapore. The innovative use of information technology has increased efficiency and reduced costs for the Singapore trading community (Koh, 2017).

Singapore Customs pays great attention to the quality of their work and creating a positive image. Therefore, on the official website of the organization, like large firms, not only the mission and principles of work are indicated, but also the time frame during which the customs undertake to respond to emails and inquiries. For some operations, the process takes only a few minutes. The agency notes that it strives to provide excellent service, and their main pride is satisfied customers. 
Singapore Customs Customer Service Standards (Koh, 2017)

\begin{tabular}{|c|c|}
\hline Operations & Terms \\
\hline \multicolumn{2}{|c|}{ FOR BUSINESS } \\
\hline Reply to emails and inquiries & 3 days \\
\hline $\begin{array}{l}\text { Submission and editing of the declaration through } \\
\text { the system TradeNet }\end{array}$ & $99 \%$ within 10 minutes \\
\hline $\begin{array}{l}\text { Obtaining a license to store goods in a warehouse } \\
\text { with zero tax on goods and services }\end{array}$ & 7 working days \\
\hline Refund of tax on GST on imported goods & $\begin{array}{l}5 \text { working days (with accompanying documents, } 12 \\
\text { working days without accompanying documents) }\end{array}$ \\
\hline $\begin{array}{l}\text { Obtaining a certificate of origin (via the online } \\
\text { application) }\end{array}$ & $\begin{array}{l}\text { For goods produced in Singapore }-2 \text { hours, upon } \\
\text { receipt of preferential certificates for re-export of } \\
\text { goods }-2 \text { working days }\end{array}$ \\
\hline Issuance of import certificates and references & 2 hours \\
\hline Requests for customs regulations & $\begin{array}{c}30 \text { days from the date of receipt of the full package } \\
\text { of documents }\end{array}$ \\
\hline \multicolumn{2}{|c|}{ FOR TOURISTS } \\
\hline approval of a tax refund request & $95 \%$ within 10 minutes \\
\hline $\begin{array}{l}\text { the process of assessing the collection of duties on } \\
\text { goods of tourists / crew members }\end{array}$ & $95 \%$ within 8 minutes \\
\hline $\begin{array}{l}\text { obtaining a permit for the export of goods in hand } \\
\text { luggage (hand-carried exports scheme }\end{array}$ & $95 \%$ within 15 minutes \\
\hline
\end{tabular}

This system is considered as public-private, so a fee is charged for its use, however, the amounts are quite modest - 20 Singapore dollars (about $420 \mathrm{UAH}$ ). Monthly for the presence of an account and 2.88 Singapore dollars (about $60 \mathrm{UAH}$ ). For each operation.

It should be added that money for transactions and accrued taxes are deducted from clients' accounts automatically - the system is also two-way interconnected with other state bases.

Future plans for the Singapore developers include further integration of the TradeNet system with the commercial information systems TradeXchange - a platform that simplifies the exchange of information in the supply chain between logistics and trading companies (Busol, 2017).

Table 2

Benefits of using the TradeNet system (https://www.tradexchange.gov.sg, 2017)

\begin{tabular}{|c|c|c|}
\hline Name & $\begin{array}{l}\text { Before using TradeNet } \\
\text { (when using the manual feed } \\
\text { documentation) }\end{array}$ & $\begin{array}{c}\text { while working with the TradeNet } \\
\text { system }\end{array}$ \\
\hline submission of documents & through exporters & without leaving office \\
\hline submission of documents & only during working hours & $24 / 7$ \\
\hline $\begin{array}{l}\text { number of visits to regulatory } \\
\text { authorities, for each document }\end{array}$ & at least 2 visits were required & not required \\
\hline number of copies of documents & a plenty of (approx. 35 forms) & $\begin{array}{c}\text { only } 1 \text { copy (can be printed only } \\
\text { by user) }\end{array}$ \\
\hline $\begin{array}{l}\text { term of consideration of the } \\
\text { application }\end{array}$ & from 4 hours to 10 days & within 10 minutes \\
\hline $\begin{array}{l}\text { import / export of goods subject to } \\
\text { duty }\end{array}$ & $\begin{array}{c}\text { submission of individual } \\
\text { documents for customs clearance }\end{array}$ & $\begin{array}{l}\text { the same document is sent to } \\
\text { customs for processing }\end{array}$ \\
\hline $\begin{array}{l}\text { import / export of goods, which is } \\
\text { subject to restrictions }\end{array}$ & $\begin{array}{l}\text { issuance of individual documents } \\
\text { to various regulatory authorities }\end{array}$ & $\begin{array}{l}\text { the same document is sent } \\
\text { to regulatory authorities for } \\
\text { processing }\end{array}$ \\
\hline levied fee & 10-20 Singapore dollars & 2,88 Singapore dollars \\
\hline duty collection method & using checks (bills) & $\begin{array}{c}\text { automatic debiting of funds from a } \\
\text { bank account }\end{array}$ \\
\hline
\end{tabular}


Singapore has its own rules for companies that want to do foreign trade. In order for the company to obtain this right, an account must be created at the Singapore Customs, which is made for 1-2 days and is valid for the entire period of the company's existence. Further, in order to import or export a company's goods, it is necessary to obtain through the TradeNet system a permit of the appropriate type - "IN" or "OUT", and permits from specialized regulatory authorities may also be required if, for example, cigarettes, medicines or foodstuffs are transported (Busol, 2017).

Despite the fact that there is a free trade zone in Singapore, and most goods are not taxed, some goods will still have to pay tax - these are alcoholic beverages, tobacco products, cars and oil products. In addition, all goods imported into the country for domestic consumption are subject to the GST goods and services tax, which is collected by the Singapore customs. For all goods, its size is the same $-7 \%$ of the cost of goods.

Since there are many industries in the country, the products of which are then exported within the framework of re-export, there are a number of simplifications for business associated with the return of GST or the delay in payment. So, for example, there is a program for large trading companies whereby they can postpone the payment of GST until the final point of entry (Koh, 2017).

There are also special FTZs in seaports and airports, where taxes are temporarily not levied on imported goods. In turn, GTS and duties must be paid only after the goods leave this territory and enter the customs zone. This scheme is widely used for transshipment of goods and re-export of goods (Koh, 2017).

Licensed warehouses with zero GST operate in a similar way - payment of duties and taxes on goods moved to its territory is postponed until export.

The main achievement of the Singapore Customs is the single window system, which has received many awards from international organizations.

Singapore became one of the first countries to introduce electronic technology in customs clearance.

In addition to the American one, Singapore and Swedish, working on the principle of "single window", are considered to be the most advanced models of customs activity in the world today. So, for example, in Singapore, all interactions of participants in foreign economic activity pass through the authorized state body, and in the future information is sent to the customs authorities, veterinary and sanitary services, tax and banking systems of the state. Electronic declaration works $100 \%$ in Singapore (Koh, 2017).

The reason for the establishment of a Single Window in Singapore should be determined starting from the prehistory - in the mid-1980s, the Singapore government decided to simplify and streamline trade authorization procedures in order to further strengthen Singapore's status as a trade center and improve the situation in foreign trade. To provide adequate support for the use of information technology to review and improve trade laws and procedures, ad hoc committees have been established with the participation of senior government officials and leading representatives of the business community. Thus, the chairman of the supervisory board, which oversaw the plans and their implementation, was the Minister of Trade and Industry, Brigadier General Lee Sien Loon (the current Prime Minister of Singapore).

Today, $100 \%$ of all declarations are submitted through the system and 9 million applications for trade permits are processed through it every year.

Work on creation of TradeNet began in 1986. The developers took as a basis the principle of reducing the number of interfaces with which the user must interact. A huge amount of work was done to standardize the forms of documents, change the work of existing departmental programs and restructure all processes of interaction between departments. A private company, Crimson Logic Pte Ltd., was established to build and maintain the system (Busol, 2020).

TradeNet is a multifunctional system. The submitted documents are automatically checked against the codes of the Harmonized System, syntactic check and analysis is carried out on the basis of normative acts. It is also possible to cancel the application and receive a refund of the already paid processing fee. More than $90 \%$ of applications are processed without the manual intervention of customs officers or employees of other authorities, and users can receive and print an import permit within 10 minutes (Busol, 2020).

Today, the system provides businesses with the ability to submit documents to all the necessary authorities (Singapore customs and regulatory authorities) electronically through a single electronic window. Within 10 minutes after filing an application for a permit, the applicant is given an electronic response indicating the decision (issue or refusal to issue a permit), as well as the conditions of issue or reasons for refusal (Khomutenko, 2017). 
TradeNet, the world's first nationwide trade filing system, is recognized as a major contributor to an enabling environment for doing business in Singapore. The innovative use of information technology has increased efficiency and reduced costs for the Singapore trading community. The TradeNet System was launched on January 1, 1989 The Government believes that the implementation of the TradeNet System will bring significant benefits to the Singapore trading community, and therefore to the economy as a whole. Large cost savings, efficiency gains and shorter processing times are a consequence of the use of TradeNet, which has greatly improved the competitiveness of Singapore as an international trade center (Khomutenko, 2012).

Thus, among the main innovations to simplify customs procedures, one should highlight the introduction of a "single window" system for the implementation of various types of state control based on the use of electronic technologies. "Single window" is an electronic data exchange system that allows various government services to automatically exchange information about the cargo that passes through the customs border and the results of its passing the necessary types of control. The concept of a "single window" occupies a leading place in the practice of customs clearance in many countries of the world - Japan, Singapore, the USA, Senegal, the countries of the European Union, since it facilitates the simplification of customs formalities, trade procedures and allows parties - participants in trade and transport operations to submit standardized information and documents using a single channel to comply with all regulatory requirements for the import, export or transit of goods and vehicles Single Window models differ in the way they are financed: in Finland, Sweden and the United States, the system is fully supported by the state; in Guatemala it is the private sector, and in Hong Kong, Malaysia, Mauritius, Senegal and Singapore, single windows operate on the basis of public-private cooperation (Khomutenko, 2017).

In the national legislation of Ukraine, the regulatory framework for the functioning of a "single window" is defined in the Resolution of the Cabinet of Ministers of Ukraine dated May 25, 2016 № 364 "Some questions of realization of the principle of a "single window" when implementation of customs, sanitary and epidemiologic, veterinary and sanitary, phytosanitary, ecological, radiological and other types of the state control".

The interaction of enterprises, customs and regulatory authorities on the principle of a "single window" is carried out using an information and telecommunication system that receives information, processes it and automatically appropriate messages for all involved subjects. The "single window" system provides for the creation of a unified electronic database, which allows state bodies authorized to carry out the relevant types of control and structural divisions of customs to automatically exchange information about the cargo that moves across the customs border of Ukraine. All types of control (customs, sanitary and epidemiological, veterinary and sanitary, phytosanitary, environmental, radiological) are carried out using electronic data exchange. Thus, instead of seals and stamps of government agencies, electronic marks are put on paper documents in a common database (Raxman, 2016).

The creation of a "single window" helps to simplify customs procedures and reduce the time spent on them, minimizes the influence of the human factor in decision-making by officials of the revenue and collection authorities and regulatory authorities, which will significantly reduce corruption risks and opportunities for abuse of office.

The advantages of a Single Window are obvious:

- inspection of goods is carried out simultaneously by all regulatory authorities;

- $\quad$ costs for business are reduced, because the passage of control provides for a reduction in contact between business and regulatory agencies;

- the regulatory authorities have only 4 hours to decide on the appropriate type of control. If within four working hours from the moment of receipt of e-mail and scanned documents via the web interface, the authorized official of the supervisory authority did not enter any decision into the information system, in this case the principle of "tacit consent" is applied, that is, the system automatically considers that the corresponding types state control has been carried out. This decision is the basis for the completion of customs control and customs clearance of goods transported across the customs border of the state.

It should be noted that, as evidenced by world experience, most countries are not ready for changes in the field of simplification and harmonization of customs procedures at the universal and regional levels. This is confirmed by the publication of the report at the World Economic Forum in 2008 (The Global Enabling Trade report 2008), according to which Singapore is recognized as the country with the least 
burden of customs procedures with an indicator of 6.4 (on a 7-point rating scale, where 1 is slow in time and cumbersome customs procedures, 7 is fast and effective passage) (Merezhko et al., 2018).

Also noteworthy is the ease of further improvement as trade volumes and international exchange of trade information increase.

Hardware scalability. Hardware investments can be scaled up or down, depending on the predicted and required performance.

Portability and reusability. One of the advantages of J2EE technology is portability (written once when you run a program on any system) and reusability.

A key factor in the success of the TradeNet system is the Government's ability to proactively identify the problem, find a solution and implement it aggressively. In addition, the interaction of all stakeholders, systematic planning and phased implementation, as well as the right choice of technologies played an important role.

The TradeNet system increases transparency through online filing and automation of procedures. Duties, taxes and fees are collected from the participants in the trading process quickly and accurately. The payment system is directly related to banks, allows direct debiting and crediting of funds to the bank accounts of participants in the trading process and government agencies.

The automated system for checking and calculating customs taxes and fees does not allow for loss of income.

In general, the TradeNet system has significantly improved and simplified the process of obtaining permits, having an extremely positive impact on the Singapore economy (Busol, 2020).

Singapore is implementing a national supply chain security program, the Trade Security Partnership, which aims to improve overall security in international trade.

It was launched back in May 2007 based on the standards of the World Customs Organization and is an implementation of the institution of authorized economic operators.

In practice, this is a voluntary certification program in which companies commit to implementing more stringent security measures in their trading operations (Busol, 2020).

In particular, the agency has created guidelines that participants in the supply chain must follow in their work. They are designed to enable companies to identify and focus on any security gap in the supply chain, and, by closing it, provide the customer with the best level of service and a guarantee of reliability. In turn, the customs authorities, having checked the work of the company, not only provide certificates of compliance with these principles, but also enjoy some advantages in foreign trade.

The rules of procedure for the release of goods under the 2011 WCO Regional Agreement relate to release at the port of arrival without temporary transportation to warehouses or other places, the provision of guarantors in the form of surety, pledge or other relevant documents to cover the final payment of customs duties, duties, taxes, and the like. For example, some agreements between the United States and its trading partners (including Chile, Peru, Colombia, Singapore, Australia, Oman, and Morocco) require goods to be released within the time required to ensure compliance with customs laws and regulations (but no longer than that, and, if possible, within 48 hours of arrival) (Prokopenko, 2018).

The Customs Service is part of 14 ministries that make up the civil service as a whole, there are committees, which are characterized as autonomous government agencies, created in accordance with acts of parliament to perform certain functions depending on the branch of the civil service. They are not subject to the legal privileges of government ministries, but they have great independence and flexibility. A specific system of activities of the customs service, based on 10 principles, is applied to any of the types of public service, including the customs one. It was first introduced as a principle by the British in 1951, when the country's leadership emphasized the dependence of career advancement on a person's abilities. So, the gifted and the best, after four or six years of work for the government, go to public service. The civil service is protected from political interference. Competitive salaries - the guarantee that talented employees do not go to work in the private sector of a Singaporean employee can be described as follows: honest, competent, efficient, well paid, but constantly under pressure. Computerization has helped cut employees. Another limiting point is the fact that job offers must be substantiated (http://ukrexport.gov.ua, 2020).

The effectiveness of the service is a consequence of strict discipline, perseverance and diligence of officials, low levels of corruption, recruiting the most capable candidates based on the principles of meritocracy, excellent training, regular campaigns aimed at improving the quality of services provided, high demands from the country's political leaders, tireless striving for excellence. 
The success and excellence of the Singaporean civil service lies in how these principles and practical implications are integrated into one complex, which is then intensively and carefully applied and supported by appropriate resources, thoughtful planning, strict discipline and comprehensive instructions. Feedback and consistency are important elements of the Singapore system.

The state reveals promising students at an early age, observes and encourages them during their studies. They receive scholarships to enter universities, some go abroad. In turn, promising students pledge to work for the government for four to six years, and some of them are offered to join the Popular Action Party (hereinafter - PAP). During the 1991 general election, with 11 new PAP candidates, 9 were from the public service and 2 from the private sector. During the 1997 general elections, with 24 new candidates, 15 were from the public service and 9 from the private sector. Thus, the best and most gifted move into civil service, and government-linked companies (GLCs) in Singapore have access to this stock of human resources. Indeed, some senior officials are members of the board of such companies and may be recruited to work for them on a permanent basis.

There is a shared ideal of integrity in the public service in Singapore. Strict laws and regulations, as well as severe disciplinary action from the Civil Service Commission and the Bureau of Corruption Investigation, discourage engaging in corruption-related activities. The personal example of political leaders and highranking officials also sets the tone for others to follow (Koh, 2017; Merezhko et al., 2018).

At the time of obteining independence in 1965, Singapore was a state with a high level of corruption in the form of bribes, gifts, embezzlement of the budget, sexual blackmail, abuse of personal influence and official position. Politics was dominated by the purchase of votes, illegal receipts in electoral funds, lobbying interests in parliament by donating certain amounts to factions. In some areas, corruption was organized and on a large scale. Customs officials received bribes to "expedite" checks on vehicles carrying contraband and prohibited goods. The staff of the Central Supplies Office (the government department that dealt with procurement and supplies) for a certain "fee" provided interested parties with information about the applications received for the tender. Officials in the Import and Export Department received bribes to expedite the issuance of permits. In the implementation of anti-corruption legislation, the role of a special agency is quite large (Prokopenko, 2018). The main functions of the CSO:

1) receive and investigate complaints containing allegations of corruption in the public and private spheres;

2) investigate cases of negligence and negligence committed by civil servants;

3) check the activities and operations carried out by civil servants in order to minimize the possibility of corruption (Koh, 2017).

Accordingly, the government's approach to fighting corruption by reducing or eliminating the incentive to commit corrupt acts was the best justification for raising the salaries of political leaders and senior civil servants. The Singaporean government has developed its own logic of the fight against corruption, namely, to minimize the ability of officials to act at their own discretion, that is, to reduce the number of required signatures on documents. There should be a clear line between government responsibilities and personal interests. In the country, the decision-making procedure was simplified as much as possible and the possibility of a double interpretation of laws was eliminated, clear and transparent rules were established for everyone, unnecessary administrative barriers to economic development were eliminated, an effective and transparent market economic system with a minimum licensing system was created.

Also, the inevitability of punishment is the first factor deterring corruption. Activities should concern both parties: those who give bribes and those who take them. No one - not a minister, not a member of parliament, not a high-ranking official - can stand above the law. The centerpiece of Singapore's anti-corruption policy has become (and continues to function to this day) a permanent specialized anticorruption body - the Corruption Investigation Bureau, which has political and functional autonomy and whose head reports directly to the Prime Minister (Busol, 2017).

The next and last link in the fight against corruption and bringing the country to the international level is the introduction of wages that correspond to the market level. As the President of Singapore said, "We decided to pay civil servants and members of the government the salaries that they could earn in the private sector. If the country were not ruled by the best specialists, our story would have ended with mediocre government, unsatisfactory monetary policy and corruption" (Prokopenko, 2018).

Today, Singapore, along with China, is considered one of the countries with the lowest level of corruption at customs. However, in order to achieve such results, it took the country's authorities more 
than a dozen years. Like other Asian countries, bribery has historically been an integral part of the culture and life of society.

The customs authorities were also no exception - it was necessary to pay a bribe to pass the contraband and "speed up" the inspection of vehicles. However, over time, this approach began to threaten not only the security of the state, but also further economic growth. Therefore, as in China, the authorities decided to fight corruption with harsh methods - the introduction of criminal liability and a sharp increase in fines. At the same time, the minimum fine for a corruption offense is from 100,000 Singapore dollar (Koh, 2017).

Another element of the anti-corruption program was the presumption of guilt of a government agent or other agency. According to her, an employee is obliged to prove his innocence before a court on his own. Moreover, if the accused lived beyond their means or owned excessively expensive properties, then this will also confirm that the accused had corrupt income. If the official's guilt can be proved, then he faces a fine, confiscation of funds and imprisonment for a term of 10 years or more, and the bribe-taker's family will be considered outraged, and none of its members will be able to get a good job in Singapore (Koh, 2017).

Despite all this, the work of a Singaporean civil servant is considered not only prestigious, but also highly paid, while the level of salary is tied to the average salary of persons working in business in comparable positions.

In addition, great attention in the framework of the fight against corruption is paid to its public coverage. For example, in 2016, Prime Minister of Singapore Lee Hsien Loong presented an honorary award to customs officer Siou Tek Meng for rejecting a bribe from a tourist who came to Singapore. The negligent traveler himself received 3 weeks in prison.

In addition to the customs officer, 34 more civil servants and 13 civilians received high marks at the solemn event.

The public service of Singapore is considered one of the most effective in Asia, this efficiency is the result of strict discipline, perseverance and hard work of officials, low levels of corruption, hiring the best candidates based on the principles of meritocracy, excellent training, regular campaigns aimed at improving the quality of the provided services, high demands from the political leaders of the country, relentless pursuit of excellence. Officials are provided with the necessary equipment, computers, and air conditioners necessary in the hot and humid climate of Singapore (Khomutenko, 2020).

The effectiveness of government policy implementation is also related to the small size of the country; careful planning and foresight of the problems that may arise in the future, the government of the country enjoys a good reputation, which has been deserved for many years and makes its stay in power even more legitimate; providing adequate resources; public support, which is achieved through educational activities and publicity; the discipline of a people who takes tough but necessary measures, such as strict rules that must be followed in order to buy and use a car.

The effectiveness and efficiency of the public service is also explained by the desire to achieve concrete results. The civil service is neutral and not involved in politics. Civil servants are not allowed to go on strike because their work is considered a vital service. This tradition of neutrality has been inherited from the British and allows for the continuity of the civil service in the face of political change. Neutrality does not translate into a decline in the quality of services or a decrease in commitment to serving the public. Neutrality also does not lead to a loss of persistence in striving to achieve the goals set for the state. In its work for the good of society, the public service must act fairly and impartially, but neutrality does not concern the conduct of government policy: the implementation of government policy must be decisive, effective and responsible (Koh, 2017). The civil service must clearly understand the national interests of the country. The civil service has set a goal that every employee must complete at least 100 hours of training per year.

For example, in order to train employees to work with the TradeNet system, in addition to other basic computer skills, three key topics were identified, on which training was conducted before the implementation of the system:

- business process management and their restructuring;

- adoption of standards;

- $\quad$ subject knowledge in the field of trade documentation.

Data were examined on users and found out what training each of them needs. Then various categories of users received appropriate training (Busol, 2020). 
The Civil Service College, with the help of the Institute for Policy Development and the Institute of Public Administration and Management, are constantly revising their curricula to help create the conditions necessary for the implementation of government and community initiatives. Established relations with foreign state institutions and services, allows you to use the experience of public services around the world, to receive information regarding education and training. In addition, the College of Civil Service conducts special courses to help educate civil servants in the skills necessary to operate in an increasingly demanding society. Moreover, the civil service unit plays a central role in shaping and revising personnel management policies and decides on the appointment to a particular position, as well as on the training and performance appraisal of government officials (Khomutenko, 2020).

\section{Conclusions}

It is important to take into account the experience of the formation and functioning of the Singapore customs service at the stage of searching for an effective model of customs management in Ukraine in the direction of improving the organizational structure, introducing new approaches to the implementation of customs formalities and strengthening the personnel potential of customs authorities.

\section{References:}

1. Busol, O. (2020). Klyuch do Uspixu Ukrayiny - minimizaciya korupciyi (dosvid Singapuru) [The key to Ukraine's success is minimizing corruption (Singapore's experience)]. Lex. Inform. Yurydychni novyny Ukrayiny. Retrieved from: https://lexinform.com.ua/dumka-eksperta/klyuch-do-uspihu-ukrayinyminimizatsiya-koruptsiyi-dosvid-singapuru/ [in Ukrainian].

2. Koh, J. (2017). Singapore TradeNet Single Windows \& Regional Interoperability - Trends and Considerations. Retrieved from: https://www.unescap.org/sites/default/files/26\%20Apr $\% 202017 \% 20-\% 20$ Singapore\%20Experience.pdf [in English].

3. Ministry of Economic Development and Trade of Ukraine (2011). Derzhavna pidtrymka ukrainskoho eksportu. Sinhapur[StateExportSupport. Singapore]. Ukrexport.gov.ua. Retrieved from:http://ukrexport.gov.ua/ ukr/country_brief/?country=sin [in Ukrainian].

4. Merezhko, N., Karavaiev, T., Kaluha, N. (2018). Podolannia barieriv u mizhnarodnii torhivli cherez sproshchennia mytnykh protsedur [Overcoming barriers to international trade through simplification of customs procedures]. Zovnishnia torhivlia: ekonomika, finansy, pravo. Seriia "Ekonomichni nauky", no. 3, pp. 5-20 [in Ukrainian].

5. Ministry of Economy of Ukraine (2020). Komitet asotsiatsii Ukraina - YeS u torhovelnomu skladi [EUUkraine Association Committee in trade compositioni]. Retrieved from: https://me.gov.ua/old/Documents/ Detail?lang=uk-UA\&id=d7ca9010-7837-4040-ab1e-b739b7166b31\&title=KomitetAsotsiatsiiUkrainasUTorg ovelnomuSkladi [in Ukrainian].

6. Ministry of Economic Development and Trade of Ukraine (2020). Derzhavna pidtrymka ukrainskoho eksportu. Sinhapur. Ekonomichne spivrobitnytstvo [State Export Support. Singapore. Economic cooperation]. Ukrexport.gov.ua. Retrieved from: http://ukrexport.gov.ua/ukr/econ_spivirob/sin/5023.html [in Ukrainian].

7. Olujko, V.M. (ed.) (2018). Upravlinnia personalom v umovakh detsentralizatsii [Personnel management in a decentralized environment]. Kyiv, 504 p. [in Ukrainian].

8. Prokopenko, L.S. (2018). Ekonomichni zviazky Ukrainy z rozvynutymy krainamy [Ukraine's economic ties with developed countries]. Elektronnyi naukovyi zhurnal, no. 4. Retrieved from: https://osvita.ua/vnz/reports/econom_theory/22185/ [in Ukrainian].

9. Rahman, M.S., Siladi, K.B.(2018). Kharakterystyka ta analiz suchasnoho stanu zovnishnoekonomichnoi diialnosti Ukrainy [Characteristics and analysis of the current state of foreign economic activity in Ukraine]. Efektyvna ekonomika, no. 10. Retrieved from: http://www.economy.nayka.com.ua/pdf/10_2018/32.pdf [in Ukrainian].

10. Khomutenko, V., Zaporozhets, O. (2012). Orhanizatsiini modeli mytno-podatkovoho administruvannia $\mathrm{v}$ zarubizhnykh krainakh [Organization models of customs tax administration in foreign countries]. Retrieved from: http://ua-ekonomist.com/164-organzacyn-model-mitno-podatkovogo-admnstruvannya-v-zarubzhnihkrayinah.html [in Ukrainian]. 


\title{
КОМПАРАТИВНИЙ АНАЛІЗ ОРГАНІЗАЦІЙНО-УПРАВЛІНСЬКИХ МОДЕЛЕЙ ФУНКЦІОНУВАННЯ МИТНИХ АДМІНІСТРАЦЙ (НА ПРИКЛАДІ МИТНОЇ АДМІНІСТРАЦІЇ СІНГАПУРУ)
}

\author{
Віктор ЧЕНЦОВ, \\ перший проректор \\ Університету митної справи та фінансів, \\ доктор історичних наук, доктор наук з державного управління, професор \\ chentsov61@gmail.com \\ orcid.org/0000-0002-1109-8168 \\ Наталія ТКАЧУК, \\ студентка \\ Навчально-наукового інституту права та міжнародно-правових відносин \\ Університету митної справи та фінансів \\ vnv.vlasenko@gmail.com \\ orcid.org/0000-0001-7848-1076 \\ Ермек УССКССВ, \\ професор кафедри бізнесу $і$ комунікаціі \\ Киргизького національного університету імені Жусупа Баласагина, \\ доктор філософських наук, дочент \\ ermekadil@gmail.com \\ orcid.org/0000-0001-7848-1076
}

\begin{abstract}
Метою дослідження є теоретико-методологічне обтрунтування механізмів державного управління митною справою на засадах компаративного аналізу та розроблення напрямів їх удосконалення на прикладі митної адміністраиії Сінгапуру.

Методи дослідження. Для досягнення мети дослідження був використаний комплекс загальнонаукових $і$ спеціальних методів. Зокрема, були застосовані такі методи:

- діалектичний - для розуміння взаємозв'язку основних понять, що становлять основу державного управління митнищею;

- системний - для надання характеристики системи державного управління митниею та визначення права власності на параметри митної системи;

- порівняльний аналіз - для вивчення зарубіжного досвіду державного управління митницями;

- структурно-функиіональний - для порівняння зарубіжного досвіду державного управління митнииями та визначення показників для діагностики структурно-функціональної динаміки державного управління митницями;

- метод моделювання - для розроблення діагностичної моделі.

Результати. Новизна дослідження полягає в теоретико-методологічному обтрунтуванні механізмів державного управління митною справою на засадах порівняльного аналізу світового досвіду та у визначенні напрямів їх удосконалення.

Зокрема, у статті комплексно розглянуто та здійснено теоретико-методологічне обтрунтування механізмів державного управління митною справою, щчо сприятиме впровадженню європейських принципів стратегічного розвитку митниці в сучасну модель державного управління в Україні. На основі порівняльного аналізу досвіду держсавного управління митною справою визначено та класифіковано механізми й інструменти регулювання митних відносин на глобальному, регіональному та національному рівнях.

Висновки. Досвід становлення й функиіонування митної адміністращії Сінгапуру необхідно враховувати на етапі пошуку ефективної моделі управління митною справою в Україні в напрямі вдосконалення організаційної структури, упровадження новітніх підходів до реалізації митних формальностей, укріплення кадрового потенціалу митних органів.
\end{abstract}

Ключові слова: спрощення митних процедур, митні адміністрації, митні формальності, TradeNet, імпортери, експортери, антикорупція, контрабанда. 